\title{
Budist Çevreye Ait Eski Uygur Türkçesi Dönemi Metinlerinde "Kadın"
}

\author{
Muammer ŞEHITOĞLU*
}

\section{Özet}

Tarihsel süreçte Türkçe birçok kavram, terim ve kavram işaretini yazılı metinler aracilığıyla bir sonraki kuşağa aktarmış ve o kavram, terim ve kavram işaretleri dilin gelişim ve değişim sürecinde değişen kültürel coğrafya ve zamana bağlı olarak sürekliliğini devam ettirmiştir. Eski Uygur Türkçesi Dönemi de Türkçenin bu türden değişim ve gelişimini gösterdiği önemli tarihî dönemlerden biridir. Özelikle Budist çevreye ait metinlerin önemli bir bölümünün Eski Uygur Türkçesine Toharca ve Sanskritçeden uyarlanarak çevrilmiş olmaları zengin bir kavram, terim ve kavram işareti varlığını ortaya çıkarmıştır. Kadın için işaretlenen kavramlar da bu açıdan ilgi çekicidir.

Çalışmada Budist çevreye ait metinlerdeki bu türden kavram işaretleri ile ilgili açılamalar yapılacak, bir önceki ve bir sonraki tarihsel dönemlerdeki kullanımlar ile ilgili karşılaştırmalara yer verilecektir. Hangi metinlerde ne türden kavram işaretleri, sözcükler ve terimler kullanıldığ açılanacaktır. Ayrıca işaretlenen kavramların, sözcüklerin ve terimlerin de unvan mı yoksa bir sıfat mı olduğu konusu üzerinde de durulacaktır.
Anahtar Kelimeler

Kadın

Eski Uygur Türkçesi

kavram işareti.

Budizm

Makale Hakkında

Geliş Tarihi: 09.01.2020

Kabul Tarihi: 22.05.2020

Doi: $10.18026 /$ cbayarsos. 672726

\section{“Woman” In Old Uighur Turkish Texts of Buddhist Environment}

\begin{abstract}
In the historical process, Turkish has transferred many concepts, terms and concept signs to the next generation through written texts, and these concepts, terms and concept signs have continued to be dependent on the changing cultural geography and time in the development and change process of language. The Old Uighur Turkish Period is one of the important historical periods in which Turkish shows such change and development. In particular, a significant number of texts of Buddhist environment were translated into Old Uighur Turkish by adapting them from Toharic and Sanskrit revealing a rich concept, term and sign. The concepts marked for women are also interesting in this respect.

In this study, explanations about this kind of concept signs will be made in the texts of Buddhist environment and comparisons will be made about the uses both in the previous and next historical periods. It will also be explained with examples in which texts and what kind of concept signs, words and terms are used. It will also focus on whether the marked concepts, words and terms are titles or adjectives
\end{abstract}

\author{
Keywords \\ Woman \\ Old Uighur Turkish \\ concept sign. \\ Buddhism

\section{About Article} \\ Received: 09.01.2020 \\ Accepted: 22.05.2020
}

Doi: 10.18026/cbayarsos.672726

* Doktora öğrencisi, Atatürk Üniversitesi Eğitim Bilimleri Enstitüsü Türkçe Eğitimi Bilim Dalı, mshtgl22@gmail.com., https://orcid.org/0000-00034471-3283. 


\section{Giriş}

İletişim, dil için en temel işlevlerden biridir. Dilin bu temel işlevi ise, onun ögeleri aracilığıyla yapılmaktadır. Görevli ve anlamlı olarak ayrılan bu ögeler; kök, köken, gövde, sözcük grubu ve cümleden oluşan anlamlı; içe ve dışa dönük elemanlar olarak da iki grup hâlinde görevli ögeler olarak değerlendirilmektedir. (Mert, 2008; Alyılmaz, 1994).

Görevli dil ögelerinden içe dönük elemanlar, yeni bir kavram işareti oluşturma yeteneklerine, işlevlerine göre sinıflandırılırken, dışa dönük elemanlar ise, yeni bir kavram işareti oluşturmayan, kullanıldıkları cümle ile ilişkileri geçici ve sınırlı olan elemanlardır. Bu elemanlar Türkçede ek, ek+ek, edat, ek+edat biçiminde ya da işaretsiz $(/+\varnothing /)$ olarak kullanilmaktadır (Mert, 2003).

$\mathrm{Bu}$ veriler 1şı̆̆ında dilin başka dillerden ödünçleyerek aldığı ve kendisinin işaretlediği kavramlar onun söz varlığını genişletmektedir. Bu bağlamda dildeki bir ögenin bir konumda bulunma ihtimali "0" a yaklaştıkça taşıdığı bilgi yükü artarken "1" e yaklaştıkça bilgi yükü azalmaktadır (Gemalmaz, 1995). Böylelikle de bir metin bağlamı içinde kullanılan anlamlı dil ögelerinin kullanımı görevli dil ögelerinden daha az sıklıktadır. Bu durumda anlamlı dil ögelerinin üzerine düşen bilgi yükü fazlayken görevli dil ögelerinin üzerine düssen bilgi yükü ise azdır. Bu nedenle görevli dil ögeleri sayı bakımından az geçiş sıklığı bakımından yüksektir. Öte yandan ise, birey kendi amaç ve gereksinimleri doğrultusunda diğer birey ve canlılarla kurduğu iletişimde o dilin söz varlığını oluşturan kavram işaretlerini kullanır ve kendi yaşayış, duyuş ve inanış biçimini ortaya koyar. Bireyin duyuş, yaşayış ve inanış biçiminin zaman içinde sürekli gelişen ve değişen yapıda olması nedeniyle de karşılaşılan her yeni durum ve koşul için yeni bir kavramın işaretlenmesi gereksinimi oluşur. Türkçe de oluşan bu yeni durum ve gereksinim için yeni kavramları işaretler ya da onları dışarıdan ödünçler. Tarihsel süreçte Türkçenin değişim ve gelişimini yansıtan dönemler ve o dönemler içinde ortaya konan yazılı ürünler bu yeni kavram işaretlerinin kullanıldığını tanıklar. Eski Uygur Türkçesi Dönemi de bu açıdan Türkçenin yeni kavramları işaretlediği ve onları dışarıdan ödünçlediği dönemdir. Çünkü bu dönemde Türkçe diğer etkileşimde bulunulan dillerden (Toharca, Sanskritçe $v b$.) dolaylı çeviri ve uyarlama aracılığıyla yeni kavramlar işaretleyerek ve ödünçleyerek söz varlığını genişletmiştir.

Eski Uygur Türkçesi Dönemi'nde Türk boy ve toplulukları birey temelinde kendilerini konumlandırırken taşıdıkları sıfatlar, unvanlar ile yaşadıkları kültürel toplum yapısında kendi rollerini ve statülerini kadın erkek ayırt etmeksizin korumuşlardır. Özellikle kadınlar ve onların statüleri toplum yapısı içinde sürekli değerli ve önemli olmuştur. Çünkü üretkenlik, anaçlık ve erdemi ile kadın, her zaman öndedir. Genel olarak düşünüldüğünde ise, Türk Kültürü'nde kadın olgusu sosyal, psikolojik ve biyolojik temelde değerlendirilmektedir. Yapılan değerlendirmeler tarihsel süreç içerisinde din, coğrafya ve kültür ekseninde farklılık, değişiklik göstermektedir. Görülen her değişiklik ise Türk boy ve topluluklarının kadına bakışını ortaya koymaktadır. (Kök)türkler Dönemi'nde Gök Tanrı inancı ile Tanrıdan "Kut" alan Kağan'ın yanında kutsî sorumlulukla görevlenen katun / hatun, daha sonraki dönemde değişik biçimlerde ve statülerde de bu sıfatını ve işlevini koruyarak devam etmiştir.

Tarihsel süreçte Uygur Türklerinde ise, özellikle din, toplum yapısı ve bulunulan coğrafyadaki yabancı kültürün (din $v b$.) etkisi ile kadın olgusu birey temelinde zihinde yer bulmaya / almaya çalışmıştır. Kadının toplumdaki rolü, işlevi, sorumlulukları da yine bu etki alanı ve düşünce ekseninde gelişmiştir. Ancak kadının birey olarak Türk geleneğindeki eşit statüsü 
devam etmiş ve hem devlet yönetiminde hem de toplumsal yaşamda önemi sürekliliğini ve etkisini korumuştur. Devletin yönetiminde Kağanların yanında yer alan katun / hatun, aynı zamanda ailenin de en büyük kolektif bilinç taşıyıcısıdır. Aynı zamanda kağanların ve boy beylerinin sorumluluğu ve seçkinliği ile birlikte onların eşi olan katun / hatun için de aynı ayrıcalık ve seçkinlik toplum içinde sunulmuştur. Yine kadın Uygur Türklerinde erkek ile eşit haklara sahip olup toplumun bütün sosyal faaliyetlerinde (Atı binme, ok atma, top oynama, güreş vb.) yer almıştır (Çandarlığlu, 2004). Bunların yanı sıra kağan eşleri için Uygur Türklerinde ayrıca K'otun Ch'eng (Hatun şehri) olarak bilinen Uygur katun / hatunlarının, prenseslerinin yaşadığı şehirlerin de mevcut olduğu bilinmektedir (İzgi, 2014). Öyle ki Türk devletlerinde kadının bu statüsünün devletin yürüttüğü siyaset için yön verici olduğu katun / hatun'un söz sahibi olduğu ve de böylelikle de bir "katun / hatunluk hukuku" nun oluştuğu kaydedilmektedir (Kafesoğlu, 2010).

Çalışmada Uygur Türklerinin, kadın algısı, onu yaşamda konumlandırdı̆̆ı yer, ailede üstlendiği sorumluluk gibi işlevleri tarihsel süreçte diğer Türk boy ve topluluklarındaki durumu ile karşılaştırılarak ele alınacaktır.

Türk boy ve topluluklarında kadının konumu ve işlevi, ilk olarak anlatı geleneğinin değişmez unsuru olan mitik bir söylem içerisinde; ait olduğu boy ve topluluğun dışında etki sahasındaki diğer toplumlara da sözlü iletişim aracılığı ile aktarılmıştır. Kimi zaman bu olgu grafiksel dil ögeleri olan kaya üstü resimler / tasvirler (petroglifler), damgalar, duvar resimleri, minyatürler, freskler gibi... görsel araçlar ile de geleceğe, sonsuzluğa / ölümsüzlüğe iletilirken; kimi zaman da anlatı geleneğinin kuşaktan kuşağa aktarılmasındaki çok değişken yapı sayesinde kadın olgusu Türk boy ve topluluklarının kolektif bilinçdışında yer alan millî kodlar ile birlikte yaşam biçimi, olay ve olguları algılama biçimi, bakış açısı ile şekillenmiştir. Ayrıca kadın olgusu sözlü anlatı geleneğinde alıcıdan vericiye taşınan mesaj aracılığı ile de oluşan her bağlam içerisinde bireyin engin hayal gücü ile zenginleşmiştir.

\section{"Kadın"a İlişkin Metinlerde Kullanılan Kavram İşaretleri, Unvanlar, Sıfatlar, Sözcükler}

Kadın olgusu, Türk kültürünün en eski dönemlerinden itibaren değişik kavram işaretleri altında ifade edilmeye çalışılmıştır : (Alyılmaz \& Alyılmaz 2014)

Katun, ebçi, eş, eşlig, evlig, kızgak,... gibi eşinin can yoldaşı, hayat mücadelesinde onun en büyük desteği, (yeri geldiğinde at binen, kulıç kuşanan, yay kurup ok atan) silah arkadaşı; evinin her şeyi; çocuğunun anası, ilk eğitmeni; kap kacak, çanak çömlek, keçe, kilim, halı... gibi, yapma ve dokuma eserlerin zanaatkâri; aile, toplum ve devlet yönetiminde ise, iktidarın imtiyazlı ortă̆ı olarak karşımıza çıkar (s. 3).

Türk kadının ayrıcalıklı ve kutsal olan bu yapısı (Kök)türk yazıtlarında da dile getirilmiştir. Tonyukuk Yazıtı'nda (Tekin, 1994)

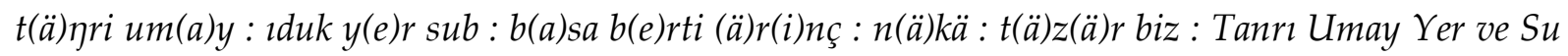
(ruhları bize) yardımcı oluverdiler. Niye kaçıyoruz? (s.17).

Köl Tigin Yazıtı'nda (Alyılmaz 2005)

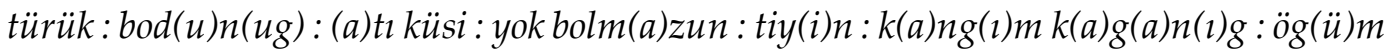
k(a)tun(u)g: köt(ü)rm(i)ş : t(e)ngri : il bir(i)gme : t(e)ngri :türük: bod(u)n : (a)tı küsi : 
yok bolm(a)zun [tiy(i)n : öz(ü)m(i)n : ol t(e)ngri] k(a)g(a)n:ol(u)rtdı (e)r(i)nç : Türk Milleti'nin adı sanı yok olmasin diye, babam kağanı ve annem katunu yüceltmiş olan Tanrı, devlet veren Tanrl, Türk Milleti'nin adı san yok olmasin diye beni o Tanr tahta oturttu (KT D 25-26, s. 11).

ifadesi yer alır. Sağlam ve ayrıcalıklı bir konumu olan kadın, kendini mitik anlamda besleyen kaynakların da taşıyıcısı konumundadır. Öyle ki Türk yaşayışı ve inanışında 5. yy'da Türk kadının kişiliğinin iki aşamada gerçekleştiği belirtilir. İlk aşamada kış aylarında ocak başında anne, aşçı olarak ama aynı zamanda ateş ibadeti görevini yerine getiren; ikinci aşamada ise, yün eğiren, yünleri, keçeleri boyayıp işleyen ve dokuyan kadın olarak betimlenir ve Ana Tanrıça Umay'ın bu kadının kişiliğini temsil ettiği dile getirilir (Esin, 1991). Bu bağlamda "Umay / Umay Ana" kavramı da yazıtlarda yer alır. Kavram kutsîyetin, anaçlığın, koruyuculuğun ve ebedîliğin imgesi olarak görülmektedir.

Yine Köl Tigin Yazıtı'nda (Alyılmaz 2005)

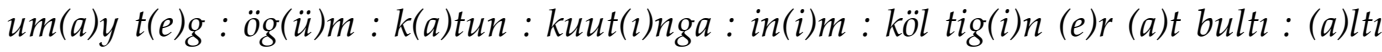
$y(e) g(i) r m i$ : $y(a)$ şınga : (e)çim $k(a) g(a) n$ : ilin törüsin (a)nça k(a)zg(a)ntı : Umay'a benzeyen annem Hatun'un kutu sayesinde küçük kardeşim Köl Tigin erkeklik / yiğitlik adını elde etti. (Henüz) on altı yaşında (iken) amcam kağanın devleti için şöyle başarılar kazandı (KT D s. 11)

şeklinde ifade edilmektedir. Öte yandan doğrudan kutlug kunçuy unvanı ile yazılmış ve bugün Çin Halk Cumhuriyeti Uygur Özerk Bölgesi sınırları içinde yer alan ve geniş bir havzayı kapsayan Turfan kentinde bulunan Çince Tapınak Kitabesindeki "Kutlug Kunçuy Yazıtı"1 da mevcuttur. Yüksek Türk kültürünün, Türk medeniyetinin ve Türk dilinin somut damgasını taşıyan yazıt, Turfandaki Turfan Müzesi'nde Çince Tapınak Kitabesinin sağ alt köşesindeki boşlukta (Kök)türk harfli olarak üç satır şeklinde yer almaktadır (Alyılmaz, 2015). Yazıtın epigrafik ve fotogrametrik belgelemesini yapıp orijinal metninin yorumlu yazı çevirimini gerçekleştirip Türkiye Türkçesi'ne aktarımını sağlayan Alyılmaz ( 2015) şöyle ifade eder:

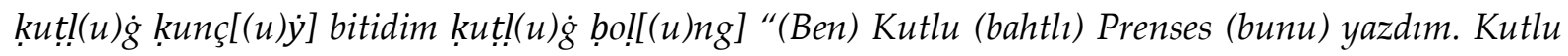
ol(un)!" (s. 353).

Yazıt metninden de anlaşılacağı üzere kunçuy kavram işareti, Prenses anlamında kullanılmıştır. Kavram işareti ile ilgili olarak Alyılmaz (2015) onun Çinceden Türkçeye (ḳunçuy் $<\ldots<$ kung-chu / kongzhu) geçtiğini ifade eder ve onun "Prenses" anlamı dişında "kağan / han soyundan küçük akraba kızları" "nesli soylu olan kadın" "kraliçe" "hanım" "bike" anlamlarının da bulunduğunu kaydeder. kunçuy kavram işareti aynı zamanda hem (Kök)türk harfli yazıtlarda hem de Eski Uygur Türkçesi Dönemi kâğıda yazılı eserlerin birçoğunda bulunmaktadır. Onlara ait bazı örnekler ise şöyledir:

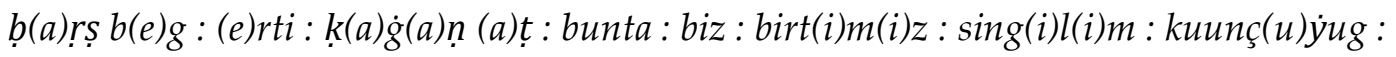
birt(i)m(i)z : özi $\dot{y}(a) n g(\imath) l t \imath: k(a) \dot{g}(a) n ̣ ı$ : ölti : bod $(u) n ı$ : küng kuul : boltı: "O zaman Kırgızların başçısı / önderi) Bars, bey idi. (Ona) kağan unvanını biz verdik. (Üstelik ona) kız kardeşimizi verdik / kız kardeşimizi onunla evlendirdik. (Ancak onlar, bütün yaptığımız iyiliklere rağmen bize) hata yaptı(lar). (Bu yüzden de) (onların) kă̆anları öldü; halkı sıkıntı çekti; cariye ve köle oldu (KT D Alyılmaz, 2005, s. 44). 


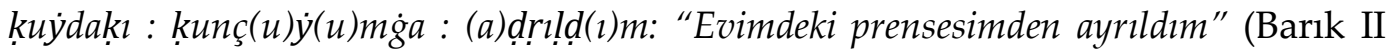
Yazıtı / E 6 2-3; Useev, 2011, s. 414; akt., Alyılmaz, 2015).

ol nomug işidip sekiz (t)ümen kunçuylar ḳutka tegdiler: Bu vaazı işitince seksen bin kraliçe ermeye / kuta ulaştılar (MS 2326-28 Tekin, 1976, s. 73).

ḳunçuyınga köngül bermedi: Prensesine gönül vermedi (İKP LXIX; Hamilton, 1998; s. 70).

DLT'de ise kunçuy; kadınların soylu, hatundan bir derece aşağı olanı (DLT Akkoyunlu \& Ercilasun, 2015, s. 746).

DLT'deki açıklamadan anlaşılacağ 1 üzere, kunçuy kavram işareti bir yönetim ve saygınlık unvanı biçiminde görülmekte ve kullanılmaktadır. Yine Kutlug Kunçuy Yazıtı'nda Alyılmaz (2015), kuțll(u)g $k u n c ̧(u) \dot{y}$ söz öbeğinin ve erkekler için soyluluk, seçkinlik, ayrıcalıklık bildiren kutlug sıfatının kadınlar için de kullanıldığını ve Eski Türkçe Dönemi'ne ait kaynaklarda

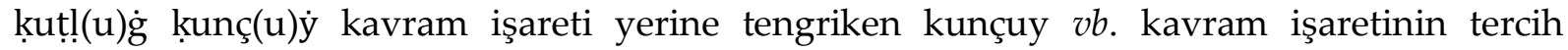
edildiğini de dile getirir.

"katun/ hatun" kavram işareti ise, tarihsel süreçte Türkler dışında Çinliler tarafından da kullanılmıştır. Ancak kaynaklarda anlam olarak farklı biçimlerde yer almıştır. Çincede khatun kavram işareti ile "kraliçe ya da prenses" anlamına dile getirilirken bir diğer kavram işareti fürén ile de "eş, kralın eşi, kraliçe" anlamında belirtilmiş ve hatun'un devlet görevlerinde etkili olduğunu dile getirmiştir. Ayrıca hatun ile kunçuy arasında hiyerarşik yapı olduğunu ve kunçuy'un kağanın kız kardeşlerine ve sonraki eşlerine verilen bir ad olduğuna vurgu yapmiştır (Tokyürek 2013). katun / hatun kavram işareti, Hunlardan bu yana hem devlet yönetiminde unvan olarak kullanılmış hem de bireysel olarak Kağan'ın eşi biçiminde tanımlanmış; devlet yönetimi içerisinde söz sahibi olma anlamında "hatunluk hukuku" oluşturarak naiplik ve devlet reisliği görevini de üstlenmişler ve "terken" unvanı ile de devleti yönetmişlerdir (Esin, 1991; İzgi, 2014; Kafesoğlu 2010). Ayrıca T'u-küe'lerde, Hunların özel bir 1rkı, yönetim unvanı olarak $K^{\prime} o-h o-t u n / K^{\prime} o$-tun biçiminin kullanıldığ 1 da görülmüştür. Ayrıca onun, Hunlardaki "Yen-çi” unvanını da karşıladığı belirtilir (Kafesoğlu, 2010). Öte yandan A. Donuk, sözcügüun etimolojisi ile ilgili F. W. Müller, W. Bang, W. Eberhard, Klaproth gibi Türklük Bilimcilerinin çeşitli görüşlerini sıralamış ve sözcüğün kökenin açıklamaya muhtaç olduğunu belirtmiştir (Donuk 1988). Bununla birlikte de Donuk, katun sözünün ilk defa Bumin Kağan'ın (552) hanımının unvanı olarak (Kök)türk Kağanlığı Dönemi'nde kullanıldığını dile getirmiştir (Donuk, 1988).

Uygur Dönemi'ne geldiğimizde ise öncelikle, "Umay / Umay Ana" kavramı sözlü anlatı geleneğinden itibaren mitolojik anlamda ele alınmıştır. Uygur Türklerinin bu anlamda mitlerinde yer alan "Esma Peri" de "Umay Ana"'nın özelliklerini yansıtmaktadır. İlgili örnekleri (İnayet, 2009) şöyle açılar:

Gökyüzü meleklerinin padişah, bütün meleklerden güzelmiş ve gökyüzünün yedinci katında yaşarmış. Tabiattaki bütün olaylar, bu meleğin keyfindeki değişimlere göre gerçekleşirmiş. Yani bu melek gözünü açsa, güneş doğup kâinat aydınlanırmış; uyusa bütün kâinat karanlığa bürünürmüş; ağlasa yağmur yă̆armış; gülse kar yă̆armış; ă̆zını açsa fırtına çıkarmış; nefes alsa rüzgâr çıkarmış. Kaşını çatsa hava bozulurmuş; sinirlense yeryüzü sallanırmış; kaşını oynatsa gök kuşă̆ı meydana gelirmiş. Bundan dolayı ona Esma Peri demişler (s. 1185). 


\section{J. P. Roux (2011), Umay için şöyle der:}

“Bu sözcüğ̈̈ zikreden Kaşgarlı Mahmud, onu 'plasenta' olarak tercüme etmektedir. Plasenta ile yakın ilişki içindedir; yeni doğmuş olanlar korumakta ve belki de bir doğurganlık tanrıçasının hatta bir ana tanrıçanın işlevini yerine getirmektedir. Umay, kiremitten yapılmış kısa Ulan Bator Yazıtında 'hanım', 'imparatoriçe' anlamına gelen hatun sıfatını taşımakta ve hanın, yani hükümdarın, göğ̈̈̈n (Tengri) yanında yer almaktadır... Kaşgarlı Mahmud taşları tekrar yerli yerine oturtmakta ve "Ĕ̆gr umaya tapınılırsa, bir çocuk dünyaya gelir." (s. 134).

diyerek, konuyu anlamaya oldukça katkıda bulunmaktadır. İnayet, bu konuda Roux'un düşüncelerine ek olarak; Umay'ın sadece kadınlar ve çocukları değil tüm kabilenin ve hayvanların da koruyucusu olduğunu belirtir (İnayet 2009: 1186). Anlaşılacağı üzere "Umay / Umay Ana" kavramı etrafında oluşan mistik / tinsel algılayış, Uygur Dönemi de dâhil olmak üzere, tarihsel süreç boyunca Türklerin kadın olgusunu ne denli önemsediğini ve onu toplumun değerli / kutsal bir parçası olarak gördüğünü ortaya koymaktadır.

Kadın olgusu, ayrıca Uygur Dönemi'nde (Kök)türklerden farklı olarak dinî inançlardan dolayı değişik algılanma biçimlerinde görülür. Özellikle ölümsüzlüğün imgesi olan mezar taşları ile ilgili kullanımlar farklılık gösterir. (Kök)türk Dönemi'nde öldürülen düşmanları temsilen diktirilen balballar, Uygur Dönemi'nde onların inançları nedeni ile hem erkek hem de kadın mezarlarında görülmez. Ayrıca yine inanç nedeni ile kadın heykel sayısı da azdır. Ama dönemin dinî, sosyal yaşamı, giyim kuşamı hakkında ayrıntılı bilgi veren duvar resimleri ve minyatürler bir hayli fazladır. (Alyılmaz \& Alyılmaz 2014).

Budizm'deki kadına bakış açısı doğrudan Uygur Türklerine yansımamıştır. Nedenlerinden en önemlisi olan "Umay Ana İnancı" ve Gök (Tek) Tanrı inancının etkileri bu durumu destekler niteliktedir. Ancak, Budizm'i kabul eden yüksek sınıftaki Türkler arasında kadın ile ilgili daha önce kabul edilen güçlü ve toplumun yönetiminde söz sahibi olan sağlam kişiliğe sahip olma değerlerinin değiştiği bunun yerine saray hanımı olarak Doğu Asya / Hint güzellik ve davranış değerlerinin benimsendiği belirtilir (Esin, 1991). Bu durumun ise, Budist kutsal kitaplarında kadının güzelliği ile ihtirasın simgesi olacağı ve bunun da Budist öğretiye inananları bilgiden yoksun kılarak ihtiraslarının ve arzularının esiri yapacağını, kurtuluşa erişemelerine engel olacağını tahmin etmek güç değildir.

Diğer yandan Budizm'de kötülüğün, şehvetin ve şeytanîliğin simgesi olan birçok dişil kavram işareti vardır. Ancak en göze çarpanı ise Buda'nın ve onun müritlerinin Nirvanaya ulaşmalarına engel olan ve ihtirasları temsil eden "Ölüm Tanrıçası Mara"dır (Eraslan 2012). Mara ile Gothama Budha'nın karşılaşması Budizm'in değiş̧ik mezheplerinde farklı hikâyeler, rivayetler ile anlatılır. Ifrit Mara'nın Geyik Parkında Gothama Budha'yı yoldan çıartmak istemesi, onu ayartmak istemesi ama Buda'nın da bunların üstesinden gelip Ifrit Mara'y kendinden uzaklaştırdığı anlatılır. (Nakamura, 2012) bu durumu Buda'nın onun baştan çıkarıcı eylemlerine karşılık;

Tanrisal olsun, insani olsun, Mara'nın tuzaklarından kurtuldum ben. Mara'nın esaretinden kurtuldum. Sen kaybettin, ölüm getiren sen. Bunun üzerine If frit Mara'nın kendisine; Muhterem Üstat beni tanıyor, Kutlu Kişi beni biliyor" diyerek kederli bir şekilde kayıplara karıştığı biçiminde anlatılır (ss. 235-236) şeklinde dile getirir. 
Belki de daha sonra yüksek ihtimalle Sanskritçe'den ödünçlenerek alınan bu kavram işareti "mara $+z$ " biçiminde dilimizde vecizeleşmiş olan "İyilikten maraz doğar" sözündeki "kötülük" anlam değerine kavuşmuş olabilir.

Türk kültür coğrafyasındaki kültürel süreklilik ve tutarlılık düşünüldüğünde kadın olgusu için yine Köl Tigin Yazıtı'nda işilik kız kavram işareti kullanılmış ve şu örneklerde ifade edilmiştir (Alyılmaz, 2005):

"beglik urı oglung kuul boltı işilik knı oglung küng boltı" "Bey olacak erkek çocuğun kul oldu; hanım olacak kız çocuğun cariye oldu" (KT D 23-24 s. 10).

Suuc yazıtında (Orkun, 1936-42) ise sadece "kız" olarak:

"algılım on yılkım sansız erti / inim yiti, urum üç, kızım üç erti / ebledim oglımın kızımın kalınsız birtüm" "A ğılım on, at sürüm sayısız idi / küçük kardeşim yedi, erkek evladım üç, kızım üç idi / oğlumu evlendirdim, kızımı çok verdim" (s. 156) ifade edilmiştir

Şine Us yazıtında (Mert, 2009) ise kızın koduzun kavram işareti kullanılmıştır:

"y\#^lkısın : barımın : kızın kod(u)zın k(e)l(i)rt(i)m" "At sürülerini, mallarını, kadınların kızların getirdim" (ŞU D3 s. 234).

Koli Çor yazıtında (Mert, 2015) kişi kavram işareti ile "eş" anlamında kullanılmıştır:

"ışb(a)ra b(i)lge : köli çor : kişi : .......bm(e)düki yok (e)rd(e)min" "Işbara Bilge Köli Çor eşi....... Acele etmediği? yok erdemin" (KÇ B8 s. 57).

Ulıg-Kem yazıtında (Orkun, 1936) ise farklı olarak yotuz kavram işareti kullanılmış ve "eş, zevce" olarak anlamlandırılmıştır:

"bodununa oglıma yotuzıma adırıltım" "Milletimden, oğlumdan, eşimden ayrıldım" (s. 58).

Budist çevreye ait Eski Uygur Türkçesi metinlerinde ise, farklı olarak éşi / işi ( eş, zevce, bey hanımı) kavramı ile işaretlendiği görülür. Eski Uygur Türkçesi Dönemi'nde Budizm etkisi ile Toharcadan uyarlama çeviri yoluyla Eski Uygur Türkçesi'ne kazandırılan Maytrısimit adlı eserde de Uygur Türklerinin kadına bakış açısına ipucu oluşturacak bu türden kavram işaretleri vardır. Örnek olarak;

"ol élig begning mahamay atlıg işi tengridin lumbani atlıg arıda aşok atlıg adınçıg söğ̈ü altınınta.." "O hükümdarın, beyin Mahamay adlı eşi, zevcesi, hanımı Tanrıdan Lumbani adlı ormanda Aşoka adlı fevkalade söğ̈̈t ă̆acı altında." (MaitrHami 1353; http://derlem.cu.edu.tr/index.php).

"tört türlüg işiler kut bultılar" "Dört türlü hanımlar, zevceler, eşler kut buldular" (MaitrHami 2352; http://derlem.cu.edu.tr/index.php).

Ayrıca eserde ana anlam değerine sahip olan ög kavram işareti de kullanılmaktadır. Metinde (Tekin, 1976) geçen örnek ise şöyledir:

"ög kaך teg eçim sintar selike bu maytrı(sm)it nom bititgeli ötüntümüz erti..." cümlesinde "Ana Baba gibi olan Sıntar Seli'ye, bu din kitabını (nom= Skr. dharma), Maytrısimit'i yazmasını rica

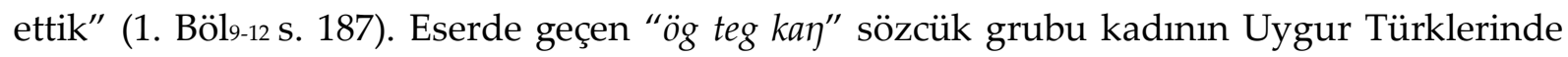
ailenin yegâne ayrılmaz parçası ve olmazsa olmazı olduğunu vurgular. Ayrıca ikileme yoluyla cümlede anlam katmanlarını genişleten kavram işareti, aile dışında olan kişilerin de ailenin başat unsuru hüviyetine büründürülebileceğini, yani kendinden birisi gibi olabileceğini göstermektedir. 
Yine aynı eserdeki (Tekin, 1976) şu örnek de dikkat çekicidir:

"bu nom bitimiş buyan edgü kılınç ülüşin evirer biz .. közünü turur kut tengrisi teg ögümüz kün silig kunçuy yüz yılka tegi uzun özin kalın kutın igsiz togasız adasız tudasız ögrünçü mengin yirtinçü mengsin ürke ögrünçülüg ermeki bolzun.." "Bu din kitabının (nom = Skr. dharma) yazılmasından hâsıl olacak sevabın (buyan edgü kılınç<Skr. punya) bir kısmını, hâlen yaşayan ve saâdet ilahesi (kut tengrisi = Skr. śridevi) gibi (olan) anamız Kün Silig Hanım'a bağışlarız. Yüz yıla yakın ömrü boyunca, büyük mutluluklarla (vücudu) hastalıksız, (yaşamı) tehlikesiz ve sevinçlerle dünyevî mutluluklarla her zaman neşeli ve bahtiyar olsun!" (Secde 139-42 s. 188).

Örnekte, eserin yazılmasından doğacak sevabın bağışlanacağı kişinin "kunçuy" unvanına sahip Kün Silig Hanım olduğu dile getirilir. Budizm etkisi ile konumu değişen Uygur kadınlarının farklı bir yönünü gösteren örnekte, eserin yazılması ile sevap alacak kadının aynı zamanda eserin bağışlayıcısı da olduğu görülür. Öyle ki bu konuda Uygur kadınlarının Budizm'e ilişkin hayır işlerinde etkin olduğu, manastır ile birlikte hastahane ve okul da yaptırdıkları dile getirilir ve bu hayır sahiplerinin de resimlerinin manastır duvarlarına çizildiği ifade edilir (Esin, 1991). Ayrıca yine Uygur İdikut Kağanlığı Döneminde Çinceden Türkçeye (ḳunçuỷ < ..<kung-chu / kongzhu) şeklinde geçen kavram işaretinin yanı sıra sık kullanılmayan "agaça" kavram işareti de "prenses" "hanım, hanımefendi" anlamlarında kullanılmıştır ve Çincedeki "a-ha-ch'a" kavram işaretinin ödünçlenmesiyle oluşturulduğu belirtilmiştir (Yunusoğlu, 2012). Ancak Eski Türkçenin kaydedilen, bilinen ilk eserlerinde (kız ve erkek) için kullanılan "ogul" kavram işaretinin ok>og sözcüklerinden türetilmiş (Alyılmaz, 2015) olması "agaça" kavram işaretinin de ok>og "döl, boy, soy, urug” kök anlamından hareketle daha sonra "ag" biçimine dönüşmüş olması da kuvvetle muhtemeldir. Öyle ki Köl Tigin yazıtında (Alyılmaz, 2005) özellikle kız çocukları için de bu kavram işaretinin “b(e)gl(i)k : urı ogl(u)ng : kuul boltı : (e)ş(i)l(i)k q11z ogl(u)ng : küng boltı” "(Senin) bey olacak oğulların (Çinliler'e) kul oldu; hatun / eş olacak kızların (ise) cariye oldu" (KT D24 s. 45) şeklinde kullanılmış olduğu görülür. Kavram işaretinin bu düşünceden hareketle ag "döl, boy, soy" +a addan ad yapan biçim birim +ça addan sıfat yapan biçim birim şeklinde oluştuğu görülmektedir. Böylelikle sıfat ve unvan olarak "prenses, hanım" anlamında "agaça" biçiminde de kullanılmıştır.

Kuanşi İm Pusar'da (Tekin, 1960) "evçi” kavram işareti ile karşılanan kadın, metinde;

“birük adın adın öge bilge atlıg yüzlüg er evçi körkin körü kurtulgu tınlılar erser kuanşi im pusar ol tınlıglarka adın adın öge bilge atlıg yüzlüg er evçi körkin körtgürü nomlayur kutgarur.." "Çeşitli, meşhur, hakîm, asîl, saygı değer erkek ve kadınların yüzünü görerek kurtulabilecek canlı varlık iseler, Kuanşi im Pusar o canlı varlıklara, çeşitli, meşhur, hakîm, asîl, saygı de ğer erkek ve kadınlar kılığına girerek görünür" (136-139, s. 22)

biçiminde geçer. Metinde geçen kavram işaretinin karşılığı olarak kadın; soylu, yüce değer yargılarını karşılamaktadır.

Altun Yaruk'ta (Tokyürek, 2015) ise kadın olgusu katun dışında, "tiši" "kadın" ve "hanım" "erkeğin eşi" kavram işaretleri ile karşılanmaktadır. Metinde;

“tiši ätözin tapladačllarta bar antag tisi tınl(i)glar bir är üzä hanımlıg bolup ätöz yänä tiši tınl(i)glar üküš ärniך kišisi bolup kamaghg bolgah tapladačı" "Kadın bedenini kabul ettiklerinde de var olan canlılar; bir erkeğe hanım olup vücudunu korumayı kabul 
edecek[tir]. Var olan yine kadın canlılar pek çok erkeğin eşi olup kamuya ait olmayı kabul edecek[tir]." (1431-1438 s. 483)

biçiminde yer almaktadır.

Mahāyāna Budizmi'nde Bodhisatvalar onlara (canlılara) merhamet, erdemleri ile yardım ederek canlıların sezgilerini anlamaya çalışırlar ve onları geçici dünyanın ihtiraslarından ve şehvetinden kurtarmak isterler. Tokyürek'in eserinde (2015), metnin Türkçe çevirisinde canlıların sezgilerinin dünyevî ve doğaüstü olarak iki türlü olduğunu; ilkinin amacının Samsara içinde gerçekleştiği ikincisinin ise Nirvanayı bulmak üzere oluştuğunu; metinde geçen "hanımlıg" kavram işaretinin ise, bu anlamda dünyevi ihtirası ve şehveti vurguladığını belirtir. $\mathrm{Bu}$ bağlamda Bodhisatvalar dünyevi ihtirasa kapılan kadın canlıların pek çok erkeğin eşi olarak yaşayacağını ve günaha gireceğini söyler. Bodhisatvaların kadınları korumak için böylesine önemli uyarılarda bulunuyor olması da kadın olgusunun bireysel ve toplumsal olarak ne kadar önemli olduğunu ortaya koyar.

Tarihsel süreçte sözlü anlatı geleneğinde kadın olgusunun algılanma biçiminin değişik örnekleri görülür. Uygur harfli metni bulunan Oğuz Kağan Destanında kadın olgusu Oğuz'un doğumu evliliği ve kimliği üzerinden değerlendirilmektedir. Eserde (Togan, 1971) "Ay Kağan'ın gözleri parladı ve bir erkek çocuk dünyaya getirdi." (s. 19) cümlesi de Umay / Umay Ana kavramından başka doğrudan Gök ve Gök Tanrı ile bağlantılı olarak düşünülmesi gerektiğini ortaya koymaktadır. Konunun bir başka yönü ise, kadının toplumsal konumudur. Ekici (2013), Oğuz Kağan Destanında evlilik ile ilgili bölümde Oğuz'un eşlerinin ailesi ile ilgili bilgi verilmediğini ve bunun da kadının toplumdaki konumunun / belirleyiciliğinin "sop" üzerinden değerlendirildiğini belirtir.

İslâmî dönem Uygur harfli eserlerin en önemlilerinden biri olan Kutadgu Bilig'de ise, kadın değişen din ve coğrafya sayesinde farklı algılama biçimlerine bürünmüştür. Yusuf Has Hacip döneminin en önemli aydınlarından biri olmasına rağmen kadına bakış konusunda son derece keskin ve katı düşüncelere sahiptir. Kadına karşı takındığı bu tavrın altında bireysel ve toplumsal birçok neden olabilir. Ancak bireysel duygularının ötesinde düşünmeye çalışırsak, dönemin seçkin ve aydın sayılabilecek kesiminin böyle bir düşünceye sahip olduğu ve Hacib'in de bu düşünce biçiminden etkilendiği varsayılabilir. Hacib, eserinde (Arat, 2007) kadını ele alırken şu ifadeleri kullanır:

"kızig tutma evde uzun begsizin,

ökünç birle ölgey özün igsizin" (4510 s. 453).

“Kızı çabuk evlendir, uzun süre evde tutma, yoksa hastalığa gerek kalmadan yalnız bu pişmanlık seni öldürür."

"aya yoldaş erdeş söz aydım kese

bu kız togmasa yig tirig turmasa" (4511 s. 453).

“Ey dost, sana kesin söyleyeyim; bu kızlar doğmasa, doğarsa yaşamasa daha iyi olur."

"kalı togsa yigrek anga yir koyı

evi bolsa koşnı ölügler toyı (4512 s. 453). 
"Eğer dünyaya gelirse, onun yerinin toprağın altı veya evinin mezara komşu olması daha hayırlıdır."

"tişilerni evde küdezgil tuçı

tişining taşı teg bolunmaz içi" (4513 s. 453).

"Kadınları her vakit evde tut, kadının içi dışı gibi olmaz."

"yatığ evde ıdma çıkarma tişig

körüp yolda algan köz ol kişig" (4514 s. 453).

"Yabancıyı eve sokma, kadını dışarıya çıkarma; bu kadınları sokakta gören göz onların gönlünü çeler."

"tişi aslı et ol küdezgü etig

yıdır et küdezmese bolmaz itig" (4519 s. 454).

"Kadının aslı ettir; eti korumalı, gözetmezsen et kokar; bunun çaresi yoktur."

“tümen ming külüg çavlıg ersiglerig

tişiler anı yirke kömdi tirig" (4525 s. 454).

$\mathrm{Bu}$ kadınlar binlerce namlı ve şöhretli kahramanları diri diri toprağa gömmüşlerdir."

Öte yandan 9. ve 10.yy'larda İslamiyet'in kabulü ile birlikte Uygurlar yeni bir din dairesine geçerek toplumsal olarak da bir değişim ve dönüşüm yaşarlar. Ancak bu dönüşüm sancılı olur. Çünkü Budist Uygurlar ile savaşmak zorunda kalırlar. Bu savaşlar sözlü anlatı geleneğinin ürünü olan efsaneleri doğurmuştur. İşte bu dönemde ortaya çıkan kadın kahramanlardan biri de Kızılçı Hanım'dır (İnayet \& Öger 2009). İnayet, Kızılçı Hanım'ın efsaneye göre; güneş ile yarışan, aydan geri kalmayan güzelliği, savaşta erkek gibi giyinmesi cesur çevik bahadır yiğit özelliği kılış ve mızrak kullanması duasının kabul olup yerin yarılması ve onu koynuna alması gibi belirli özelliklerinin Umay Ana'yı anımsattı̆̆ını belirtir (İnayet \& Öger 2009). Özellikle ortak bilinçdışında oluşan millî kodların kuşak ve zaman farkı olmadan orta çıkması da kimliğin oluşumunda bu bilincin ne kadar önemli olduğunu göstermektedir. 


\section{Sonuç}

Tarihî süreçte kadın kavram alanını temsil eden birçok kavram işareti sözlü anlatı geleneğinden itibaren değişik konuda ve temada kaleme alınmış yazılı eserlerde kullanılmıştır. Bazı kavram işaretlerinin ise, eserlerde birden fazla anlam değerine sahip olduğu tespit edilmiştir. Özellikle kunçuy kavram işaretinin hem unvan hem de sıfat olarak (Kök)türk harfli yazıtlarda ve Budist çevreye ait eski Uygur metinlerinde sıklıkla kullanıldığı görülmüştür.

Kadının Türk devletlerindeki yönetim görevlerini, yönetim yeteneğini en üst düzeyde gösteren en önemli bulgulardan biri de "Kutlug Kunçuy Yazıtı"nı yazan ve yazıtı diktiren kutlug kunçuy'un kendisidir. Yazıt ile geleceğe kalıcı mesaj verme, sözü ölümsüz kılma ve bir sonraki kuşağa kültürel millî kodları aktarma düşüncesinin, daha sonraki Uygur Dönemi'nde farklı biçimde Budist çevreye ait metinlerin uyarlanarak çevrilmesini sağlama, Budist manastır, hastahane ve okul yaptırma düşüncesine dönüştüğü görülür. Bu durum devletin üst düzey yöneticileri arasındaki Budizm etkisini açıcça göstermiştir. kunçuy'un ve katun / hatun'un siyasal gücünden ve vicdanl, merhametli kişilik yapısından yararlanarak devletin üst düzey yöneticilerinin Budist eserler aracılığıyla Budizm'in yayılmasını istedikleri görülmektedir. Mesajın içeriği, konusu türü değişse de temelde düşünce aktarım amacının aynı olduğu görülmektedir.

$>$ (Kök)türk harfli yazıtlarda yönetim unvanı ve sıfatı dışında kadın kavram alanının ög (ana), kız, yotuz (eş, zevce), kişi (eş), işilik kız (hanım olacak kız çocuk) gibi kavramlarla işaretlendiği tespit edilmiştir. Bu bağlamda kadının yaşamın içinde değişen her rolüne karşılık yeni bir kavram ile tanımlandığ 1 ve yaşam içinde etkin bir birey olduğu ortaya çıkmıştır. Buna karşılık Budist çevreye ait eski Uygur metinlerinde ise, ög (ana), éşi / işi (eş, zevce, bey hanımı), evçi (kadın) tiśi (kadın), hanım (erkeğin eşi), hanımlıg (kötü, şehvetli kadın) gibi kavramlarla işaretlenmiştir. Böylelikle kadının yaşamın içindeki konumu, kültürel değişim ve gelişimden etkilenerek karşılaşılan her durum için yeni bir kavram ile işaretlenmiştir. Kavram işaretleri içinde farklılık gösteren ise, Budizm'deki kadın algısını dünyevî şehvet ve arzu olarak karşılayan hanımlıg kavram işaretidir. Kavram işaretinin, cehaletin, bilgisizliğin sonucunda dünyevî ihtirasları karşıladığı görülür. Bilgi sahibi olunduğunda bu türden bir şehvet ve ihtiras karşılaşılmayacağ 1 da dile getirilmiştir. Kötü anlamda kullanlan bu kavram işaretinin yanı sıra "kötülüğün ve şeytanîliğin dişil simgesi olarak "mara" kavram işaretinin de kullanıldığı tespit edilmiştir. Bu örneklerden hareketle, Türk yaşayış ve inanışının kadını konumlandırışının Budizm'deki konumlandırmadan çok daha değerli olduğu görülmektedir.

katun / hatun ve kunçuy dışında Hoço / Tufan Uygur Devleti Dönemi'nde (İdikut Uygurları) agaça kavram işaretinin de "prenses, hanım" anlamında sıfat olarak kullanıldığı tespit edilmiştir.

İslamî Dönem Uygur harfli eserlerden biri olan Kutadgu Bilig'de ise, kadın kavram alanı daha önceki dönemin metinlerindeki gibi $k ı z$ ve tişi kavram işaretleri ile karşılanmış ve eserde olumsuz örnekler ile birlikte kadının toplumsal yaşamına dönük endişeler dile getirilmiştir. Egemenlik alanı kültürel olarak İslamiyetin kabulü ile değişen Türklerin, İslam dini ile ilgisi olmayan bazı yanlış ve batıl inanışlara dayalı "aydın" düşünceleri nedeniyle kadına bakış açısının değiştiği ve bu değişimden ne yazık ki o dönemin seçkin aydını Yusuf has Hacib’in de etkilendiği düşünülmektedir. (Kök)türk ve Uygur Dönemi'nde kaleme alınan ve tercüme 
edilen eserlerde olumlu anlamda kullanılan tişi ve kız kavram işaretleri ne yazık ki bu eserde yanlış bir biçimde olumsuz anlam uyandıracak şekilde kullanılmıştır.

Türk yaşayış ve inanış biçimiyle uyumlu olarak İslamiyeti kabul eden Uygurların kadın kahramanı Kızılçı Hanım'ın İslam kültürü içinde doğru bir rol model ve karakter olduğu görülmektedir.

> Tüm bu veriler 1şığında, Türk kadının kendi kimliğini yine hiçbir yanlış düşünce ve inanışın etkisinde kalmadan öz ve temiz ruhunu koruyarak Türk inanış ve yaşayış biçimiyle koruyacağ1 ve gelecek kuşağa iyi bir rol model olarak aktaracağı açıktır.

\section{Öneriler}

Tarihî olarak Türk yaşamında ve Türk inanışında kadın kavram alanını karşılayan kavram işaretlerinin anlam değerlerinin değişimini etkileyen unsurlar ile ilgili daha kapsamlı çalışmalar yapılabilir.

> Tarihî dönemlerde kaleme alınan eser metinlerinden hareketle o dönemin kadın algısı ile bugünkü kadın algısı arasında ne gibi farklılıklar olduğu üzeirne araştırma yapılabilir.

\section{Kaynakça}

Alyılmaz S. \& Alyılmaz C. (2014). Eski Türk kadın heykellerinin düşündürdükleri. Uluslararası Türkçe Edebiyat Kültür Eğitim Dergisi, Sayı: 3 (4), 1-33.

Alyılmaz, C. (2015). İpek yolu kavşağının ölümsüzlük eserleri Ankara: Atatürk Üniversitesi.

Alyılmaz, C. (1994). Orhun yazıtlarının söz dizimi (Doktora Tezi) Yükseköğretim Kurulu Ulusal Tez Merkezi'nden edinilmiştir. (Tez No: 36617).

Alyılmaz, C. (2005). Orhun yazıtlarının bugünkü durumu Ankara: Kurmay.

Arat, R. R. (2007). Kutadgu Bilig I - Yusuf Has Hacip, Metin. Ankara: TDK.

Çandarlıŏlu, G. (2004). Uygur devletleri tarihi ve kültürü İstanbul: TDAV.

Donuk, A. (1988). Eski Türk devletlerinde idarî-askerî unvan ve terimler İstanbul: TDAV.

Ekici, M. (2013). Türk tefekkür dünyasında kadın Oğuz Kağan'dan günümüze, www.enu.kz/repository ortamindan. İzmir.

Eraslan, K. (2012). Eski Uygur Türkçesi grameri Ankara: TDK.

Ercilasun, B. A. \& Akkoyunlu, Z. (2015). Kâşgarlı Mahmud Dîvânu Lugâti't-Türk, giriş-metinçeviri-notlar-dizin Ankara: TDK Yay.

Esin, E. (1991). Katun (Türk kadını'na dair). Erdem, 7(20), 471-484.

Gemalmaz, E. (1995). Türkçenin morfo-sentaktik yapısının fonolojisine etkileri. Atatürk Üniversitesi Türkiyat Araştırmaları Enstitüsü Dergisi, 3, Erzurum.

Hamilton, R. J. (2011). Iyi ve kötü prens öyküsü. Ankara: TDK.

http://derlem.cu.edu.tr/index.php).

İnayet, A. \& Öger, A. (2009). Uygur Türklerinin mitolojik, dinî ve tarihî kadın kahramanları üzerine. Turkish Studies International Periodical For The Languages, Literature and History of Turkish or Turkic Volume 4 (3), 1184-1197. 
İzgi, Ö. (2014). Orta Asya Türk tarihi araştırmaları Ankara: TTK.

Kafesoğlu, İ. (1997). Türk millî kültürü̈ İstanbul : Ötüken.

Mert, O. (2003). Türkçede hâl kategorisi ve öğretimi. Atatürk Üniversitesi Türkiyat Araştırmaları Enstitüsü Dergisi, 21, Erzurum.

Mert, O. (2008). Orhun yazıtlarında kullanılan işaretsiz (/.Ø./) görev ögeleri. A.Ü. Türkiyat Araştırmaları Enstitüsü Dergisi, 38, Erzurum.

Mert, O. (2009). Ötüken Uygur dönemi yazıtlarından Tes, Tariat, Şine Us Ankara: Belen.

Mert, O. (2015). Köli Çor yazıtı ve anıt mezar kompleksi Erzurum: Atatürk Üniversitesi.

Nakamura, H. (2012). Budha (Seyhan, Z. Çev.) İstanbul: Türkiye İş Bankası.

Orkun, N. H. (1994). Eski Türk yazıtları, IV Cilt Ankara: TDK.

Roux, P. J. (2011). Eski Türk mitolojisi (Sağlam, Y. M. Çev.) Ankara: Kabalcı.

Tekin, Ş. (1960). Uygurca metinler I Kuanşi İm Pusar Ankara : TTK Basımevi.

Tekin, Ş. (1976). Uygurca metinler II Maytrısimit, burkancıların mehdisi Maitreya ile buluşma Uygurca iptidâ̂ bir dram Ankara : Sevinç Matbaası.

Tekin, T. (2010). Orhon yazıtları Ankara: TDK.

Tekin, T. (1994). Tunyukuk yazıtı Ankara : Simurg.

Togan, V. Z., (1971). Oğuz Destanı, Reşideddin Oğuznamesi tercüme tahlili İstanbul: Enderun.

Tokyürek, H. (2013). Runik Türk yazıtlarında ve eski Uygur metinlerinde kadın hiyerarşisi. TDAY Belleten, 61(1), 119-129.

Tokyürek, H. (2015). Altun Yaruk Sudur IV. Tegzinç, karşılaştırmalı metin yayını Ankara: Bizim Büro.

Yunusoğlu, K. M. (2012). Uygurca-Çince İdukut sözlü̈̆̈̈. Ankara: TDK. 